10. Belshaw, D. (2011). What is "digital literacy"? $P h D$ dissertation. Durham University [in English].

11. Binkley, M., Erstad, O., Herman, J., Raizen, S., Ripley, M., Miller-Ricci, M., Rumble, M. (2012). Defining Twenty First Learning Skills. In Griffin, P., Mc Gaw, B., Care, E. (Eds.) Assessment and Teaching of 21st Century Skills (pp. 17-66). Dordrecht: Springer. [in English].

12. Framework for 21 st century learning. Available at: http://www.p21.org/ourwork/p21-framework [in English].

13. Gentry, R. (2012). Collaboration skills pre-service teachers acquire in a responsive preparation program.
Journal of Instructional Pedagogies, no.8. Available at: https://www.aabri.com/manuscripts/121106.pdf[in English].

14. Lewin, C. \& McNicol, S. (2015). Supporting the Development of 21 st Century Skills through ICT. In T. Brinda, N. Reynolds, R. Romeike, \& A. Schwill (Eds.). KEYCIT 2014: Key competencies in informatics and ICT (pp. 98-181). [in English].

15. Voogt, J., Erstad, O., Dede, C., \& Mishra, P. (2013). Challenges to learning and schooling in the digital networked world of the 21 st century. Journal of Computer Assisted Learning, no.29, pp.403-413. [in English].

Стаття надійшла до редакції 20.03.2019

УДК 378.4(73):63

DOI:

Наталія Гаврилюк, кандидат педагогічних наук, доцент кафедри украӥнської та іноземних мов Вінницького національного аграрного університету

\title{
ПРОФЕСІЙНА КОМПЕТЕНТНІСТЬ ТА САМОРЕАЛІЗАЦІЯ СТУДЕНТІВ ЯК ПЕДАГОГІЧНА ПРОБЛЕМА
}

Окреслено важливість проблеми становлення вищої аграрної освіти в Україні. Здійснено аналіз літературних джерел, в яких розкривається сутність понять “професіоналізаиія”, “професійна ідентифікаиія”, “професійний розвиток”, “професійне становлення”, “"рофесійна компетентність”, "професійна ідентичність", "професійне самовизначення”, “"роофесійне навчання”. Виявлено, ще професійна компетентність тлумачитися по-різному, хоча наявні певні схожості. Здійснено огляд ключових компонентів поняття "професійна компетентність".

Ключові слова: професіоналізація; професійне становлення; професійна компетентність; професійне самовизначення; професійне навчання, аграрна освіта.

Jim. 15.

Nataliya Havrylyuk, Ph.D.(Pedagogy), Associate Professor of the Ukrainian and Foreign Languages Department, Vinnytsya National Agrarian University

\section{PROFESSIONALSELF-REALIZATIONAND COMPETENCE OF STUDENTS AS A PEDAGOGICAL PROBLEM}

The importance of the problem of the formation of higher agricultural education in Ukraine is highlighted. The analysis of literary sources reveals the essence of the concepts of professionalization, professional identification, professional development, professional competence, professional identity, professional self-determination, and professional training, which determines the choice and occupation of the profession throughout life, which is considered as the basis of our study on the definition of the paths leading to the professional self-realization of future specialists in the agrarian sector.

The theoretical study has proven that under professionalization we will consider the process of formation of professional self-realization of future specialists of agrarian sector, which includes the choice of agrarian profession, taking into account its own capabilities and needs; assimilation of the rules and norms of the profession of agrarian; self-awareness as an agrarian; self-development by means of the profession; the process of entering a future specialist into a profession.

Professional competence is interpreted: 1) as a personality trait, namely, the totality of knowledge, skills, abilities, values and beliefs that are used to set goals in their future professional activity of the guidance and personality characteristics of a specialist, on the basis of which he defines the goals of professional activity; 2) as signs of a division. It means the activity of a specialist who uses his knowledge, skills and abilities and is able to think critically; 3) as an experience. It is stated that the personal experience of professional activity of a person is based on the acquired knowledge, values and skills that were obtained during the study; 4) as a tumor, which is the result of the received education, which promotes thesocialization of the individual and the creation of professional knowledge; 5) as a combination of competencies, general-purpose and narrow-professional.

It has been found that professional competence is interpreted differently, although there are certain similarities. A review of the key components of the concept "professional competence" was conducted.

Keywords: professionalization; professional formation; professional competence; professional selfdetermination; vocational training; agrarian education.

П

остановка проблеми. На сучасному етапі розвиток вищої аграрної освіти є надто актуальною темою, адже вона

знаходиться під сильним впливом перетворень у сучасному суспільстві. Під час освітніх змін головним завданням у системі вищої аграрної 
освіти є підготовка висококваліфікованих та конкурентоспроможних фахівців, які спроможні негайно реагувати на швидкі зміни умов праці. Проблема підготовки студентів до їх професійної діяльності або їх самореалізація - $є$ одною 3 головних проблем в освіті, яка покликана в майбутньому визначати шлях держави та іiі нішу у сучасній цивілізації. Виходячи з актуальності проблеми, окреслимо мету дослідження, яка полягає у теоретичному огляді базових понять нашого дослідження, зокрема "професійної самореалізації”, “професійної компетентності”, “професіоналізації”.

Професійне становлення особистості з ї можливостями, які пов'язані із входженням у професійну діяльність розглядається багатьма дослідниками (Т. Артюхова, Н. Бурмакіна, Е. Клімов, Р.Кравець, С. Краснопьорова, Т.Кудрявцев, О. Мамічева, С. Максименко, А. Маркова, В. Машин, Н. Ничкало, В. Осьодло, Ю. Поваренков та інші).

Виклад основного матеріалу. Слово “професія" має латинське погодження (professio - заявляю про себе, про свій фах). Крім поняття “професійна самореалізація" у науковому обігу вживаються ще поняття "професіоналізація", “професійна ідентифікація”, "професійний розвиток”, “професійне становлення”, “професійна компетентність”, “професійна ідентичність”, “професійне самовизначення”, “професійне навчання”, які детермінують вибір та опанування професією протягом усього життя.

Трактування поняття “професіоналізація”. Професіоналізація передбачає набуття знань, умінь та навичок та готовності особистості до професійної діяльності. Учені розглядають професіоналізацію як мобільність людини в суспільстві. Наприклад, Т.Ю. Артюхова розглядає професіоналізацію як складову соціалізації, тоді як становлення професіонала як один із аспектів становлення людини. Науковець стверджує, що цей процес включає в себе вибір людиною професії 3 урахуванням власних можливостей та здібностей, формування та усвідомлення себе як професіонала, збагачення досвіду професії за рахунок особистого вкладу [3]. Ми погоджуємось iз автором щодо ролі професіоналізації в житті студента закладу вищої освіти. Цей процес характеризується ідентифікацією студента з його майбутньою професією та набуттям професійної мобільності та здатності проектувати майбутню кар'єрну діяльність.

Є. Клімов розглядає професіоналізацію через етапи становлення професійної підготовки: 1) етап до прийняття рішення стосовно вибору професії; 2) етап засвоєння знань, умінь та навичок свідомо обраної професії 3) етап професійного розвитку особистості впродовж всього життя [9, 58]. Автор описує також фази професійного розвитку: 1) фаза обрання професії в навчальному закладі; 2) фаза адаптації до професії; 3) фаза набуття професійного досвіду; 4) фаза кваліфікованого виконання набугих умінь та навичок; 5) фаза набуття високої кваліфікації; 6) фаза передачі власного досвіду [8, 418 - 425]. Для нашого дослідження актуальності набуває фаза адаптації до професії.

Т.В. Кудрявцев також визначає професіоналізацію як професійне становлення, довготривалий процес, який торкається трьох ліній розвитку трансформації мотиваційної сфери професіонала, формування операційно-технічних елементів та професійного самовизначення [13].

Теоретичне дослідження довело, що під професіоналізацію можна розуміти процес опанування професією, що відображається в системних перетвореннях особистості. Отже, під професіоналізацією ми розглядатимемо процес формування професійної самореалізації майбутніх фахівців аграрної галузі, що включає вибір аграрної професії з урахуванням власних можливостей та потреб; засвоєння правил та норм професії аграрія; усвідомлення себе аграрієм; саморозвиток засобами професії; процес входження майбутнього фахівця в професію.

Ю.П. Поваренков визначає критерії професіоналізації через призму активної ролі самої людини (критерії професійної продуктивності, критерії професійної ідентичності, критерії професійної зрілості). Виокремлено співвідношення професійних можливостей із професійними вимогами, наприклад, професійна самооцінка, здатність до саморегуляції [4].

С. Максименком та В. Осьодло категорію “професійної самореалізації особистості" пов’язують 3 “професійною ідентичністю”. Науковці вважають, що “самореалізація суб' єкта включає усвідомлення, вибір і реалізацію тих аспектів індивідуальності, які сприяють його самовираженню, реалізації потенціалу, формуванню суб'єктом власної системи смислів, цінностей, мотивів, уявлень про себе, постановку цілей і визначення способів їх досягнення, у тому числі й перетворення себе" [15].

Тлумачення поняття “професійна компетентність”. Педагогічний словник дає таке визначення професійної компетентності: “професійна компетентність - це сукупність знань, вмінь, необхідних для ефективної професійної діяльності, уміння аналізувати, передбачати наслідки професійної діяльності, використовувати інформацію” $[4,78]$. 
Термін “професійна компетентність” фахівців в американській наукові літературі вперше згадується у 60-х роках ХХ століття. Дослідник Д. МакКлеланд описав особистість, пов'язуючи iï з наявністю високої мотивації і розглядав професійну компетентність як основну якість особистості, що має вплив на ефективність діяльності. Науковець конкретизує, що основними базовими характеристиками особистості $\epsilon$ мотиви, психофізіологічні особливості, знання та навички. Ми поділяємо і таку точку зору, що компетентність - це не лише отриманні знання, а здатність їх застосувати в професійній діяльності [4; 5]. На думку зарубіжних учених, професійна компетентність заснована на сукупності практичних навичок, теоретичних знань та принципів, які можна використати на практиці. Основою для визначення терміну “професійна компетентність" є підготовка працівника, який здатний конкурувати професіонально на ринку праці, при цьому мати вміння адаптуватися до швидкоплинних умов життя та бути здатним нести відповідальність за свою професійну діяльність.

Н.С. Бурмакіна об'єднує терміни “професіоналізм”, “кваліфікація”, “професійні здібності” у поняття “професійна компетентність”, що було зумовлено широтою змісту поняття і його інтегративною характеристикою $[6,50]$. Дослідник виокремлює ключові компоненти цього поняття:

1) здатність використовувати професійні уміння, отриманий професійний досвід та особистісні якості (відношення до своєї професійної діяльності, вміння ставити мету та прагнути досягнути її, вміння аналізувати, прогнозувати та застосовувати інформацію;

2) здатність вирішувати професійні питання, які засновуються на знаннях, уміннях, навичках, досвіді та цінностях, які особистість здобуває завдяки отриманій освіти і практичній діяльності;

3) здатність до психологічної готовності розвиватись завдяки своєму креативному мисленню;

4) здатність використовувати знання і вміння - тобто єдність теоретичної та практичної діяльності з подальшим винесенням суджень та аналізуванням наслідків.

Професійну компетентність тлумачать:

1) як характеристику особистості, а саме сукупність знань, умінь, навичок, цінностей та переконань, які застосовуються для поставлення цілей у своїй майбутній професійній діяльності настанов та особистісних характеристик фахівця, керуючись якими він визначає цілі професійної діяльності;
2) як ознаки діяльності. Мається на увазі діяльність фахівця, який використовує свої знання, уміння та навички та вміє критично мислити;

3) як досвід. Доводять, що власний досвід професійної діяльності людини грунтується на отриманих знаннях, цінностях та уміннях, які було отримано під час навчання;

4) як новоутворення, що $є$ результатом отриманої освіти, що сприяє соціалізації особистості та створенню у неї професійних знань;

5) як поєднання компетенцій, загальнопрофесійної та вузькопрофесійної.

В. Адольф дає визначення, що "професійна компетентність - це складне утворення, що передбачає сукупність знань, умінь, властивостей i якостей особистості, що забезпечують варіативність, оптимальність та ефективність професійної діяльності” $[1,118]$.

Р.А. Кравець пов’ язує формування професійної компетентності студентів із наявністю внутрішньої мотивації у останніх [10, 64 - 70].

Науковці розділяють професійну компетентність на складові. Наприклад, Н.Кузьміна виокремлює спеціальну компетентність; методичну компетентність у галузі способів формування знань, умінь і навичок; психолого-педагогічну компетентність і рефлексію професійної діяльності $[14,144]$.

В.Ю. Кричевський описує чотири типи професійної компетентності: функціональну, що характеризується професійними знаннями i вміннями, які іiі реалізують; інтелектуальну, яка передбачає здатність аналітично мислити; ситуативну, що має на увазі діяльність залежно від ситуації; соціальну, яка включає наявність комунікативних та інтегративних здібностей $[11,120]$.

На думку деяких дослідників способами формування професійної компетентності можуть бути:

- введення проблематики професійної компетентності до дослідницьких програм та навчальних планів підготовки майбутніх фахівців за різними освітньо-кваліфікаційними рівнями;

- проведення конференцій та семінарів 3 питань формування професійної компетентності;

- проведення та запровадження нових методик навчання та виховання 3 метою формування конкурентоздатного працівника освітньої галузі.

Висновки. Отже, під професіоналізацією ми розглядатимемо процес формування професійної самореалізації майбутніх фахівців аграрної галузі, що включає вибір аграрної професії з урахуванням власних можливостей та потреб; засвоєння правил та норм професії аграрія; усвідомлення себе аграрієм; саморозвиток засобами професіі; 
процес входження майбутнього фахівця в професію.

Професійна самореалізація майбутніх фахівців безпосередньо включає в себе ознаки професійної компетентності, яку науковці характеризують як сукупність певних знань, умінь та навичок, які опановують в процесі здобуття професійної освіти та протягом усього життя у формі набутого досвіду. Ми будемо розглядати професійну компетентність майбутнього фахівця як сукупність характеристик особистості, що проявляються в конкретній сфері діяльності, а саме сума знань, умінь та навичок з урахуванням особистісних характеристик. Так як реалізація сукупності професійних, розумових, психофізіологічних особливостей може забезпечити успішну діяльність фахівців у сучасних конкурентних умовах.

\section{ЛІТЕРАТУРА}

1. Адольф В. А. Профессиональная компетентность современного учителя : монография. Красноярск, 1998, c. 118 .

2. Антонова, О. Є. 2016. Професійно-педагогічна компетентність медичних сестер сімейної медицини: сугність, структура, технологія формування. Житомир, 2016. C. 56.

3. Артюхова Т. Ю. Профессионализация как условие раскрытия жизненного потенциала человек URL: sites.google.com/site/konfep/Home/2-sekcia/artuhova (дата звернення: 06.04.2019).

4. Балабанова, Л. В. Управління персоналом: підручник. Київ, 2011.468 с.

5.Грішнова, О. А. Економіка праці та соціальнотрудові відносини. Київ: Знання, 2006. 559 с.

6. Гура, О. І. Педагогіка вищої школи: вступ до спеціальності: навчальний посібник. Київ: Центр навчальної літератури, 2005. С. 50.

7. Демченко, С. О. Розвиток професійнопедагогічної компетентності викладачів спеціальних дисциплін вищих технічних закладів освіти: автореферат дисертації кандидата педагогічних наук. Кіровоград: Кіровоградський державний педагогічний університет імені Володимира Винниченка. 2005.

8.Климов Е. А. Психология профессионального самоопределения, 1996. с.418-425.

9.Климов Е. А. Психолого-педагогические проблемы профессиональной консультации, 1983. c. $58-61$

10. Кравець Р.А. Сутність внутрішньої мотивації пізнавальної діяльності майбутніх фахівців аграрної галузі в контексті формування полікультурної компетентності на заняттях іноземної мови. Теоретична i дидактична філологія, Переяслав-Хмельницький, 2017. Вип. 24. С. 64-70.

11. Кричевский В. Ю. Профессиограмма директора школы. Проблемы повышения квалификации руководителей школ. Москва : Педагогика, 1987. С.120.

12.Концепція педагогічної компетентності майбугніх учителів у системі ступеневої підготовки спеціалістів початкової ланки освіти. URL: http://www.kgpa.km.ua. (дата звернення: 06.04.2019).

13. Кудрявцев Т.В. Учебное пособие по курсу “Психология": Психология профессионального обучения и воспитания. Москва, 1985. 108 с.

14.Кузьмина Н. В. Акмеологическая теория повышения качества подготовки специалистов образования. Москва, 2001. 144 с.

15.Максименко С.Д. Структура та особистісні детермінанти професійної самореалізації суб' єкта URL: http://www.nbuv.gov.ua/portal/soc_gum/pspl/2010_8/319.pdf. (дата звернення: 06.04. 2019)

\section{REFERENCES}

1. Adolf, V. A. (1998). Professyonalnaia kompetentnost sovremennoho uchytelia [Professional competence of modern teacher]. Krasnoiarsk, p.286 [in Russian].

2. Antonova, O. Ye. \& Sharlovych, Z. P. (2016). Profesiino-pedahohichna kompetentnist medychnykh sester simeinoi medytsyny: sutnist, struktura, tekhnolohiia formuvannia [Professional and pedagogical competence of medical nurses of family medicine: essence, structure, technology of formation]. Zhytomyr, p. 56. [in Ukrainian].

3. Artiukhova, T. Yu. Professyonalyzatsyia kak uslovye raskrytyia zhyznennoho potentsyala chelovek [Professionalization as a condition for the disclosure of the human potential of life]. Available at: sites.google.com/ site/konfep/Home/2-sekcia/artuhova (Accessed 6 Apr. 2019). [in Russian].

4. Balabanova, L. V. (2011). Upravlinnia personalom [Personnel Management]. Kyiv, p.468. [in Ukrainian].

5. Hrishnova, O. A. (2006). Ekonomika pratsi ta sotsialno-trudovi vidnosyny [Labor Economics and Labor Relations]. Kyiv, p.559. [in Ukrainian].

6. Hura, O. I. (2005). Pedahohika vyshchoi shkoly: vstup do spetsialnosti [Pedagogy of higher education: introduction to specialty]. Kyiv, p. 50. [in Ukrainian].

7. Demchenko, S. O. (2005). Rozvytok profesiinopedahohichnoi kompetentnosti vykladachiv spetsialnykh dystsyplin vyshchykh tekhnichnykh zakladiv osvity [Development of vocational and pedagogical competence of teachers of special disciplines of higher technical educational institutions]. Extended abstract of candidate's thesis. Kirovohrad. [in Ukrainian].

8. Klymov, E. A. (1996). Psykholohyia professyonalnoho samoopredelenyia [Psychology of Professional SelfDetermination]. p. 512. [in Russian].

9.Klymov, E. A. (1983). Psykholoho-pedahohycheskye problemy professyonalnoi konsultatsyy [Psychological and Pedagogical Problems of Professional Consultation]. Moscow, p. 95. [in Russian].

10. Kravets, R.A. (2017). Sutnist vnutrishnoi motyvatsii piznavalnoi diialnosti maibutnikh fakhivtsiv ahrarnoi haluzi $v$ konteksti formuvannia polikulturnoi kompetentnosti na zaniattiakh inozemnoi movy [The essence of internal motivation of cognitive activity of future specialists of the agrarian sector in the context of the formation of multicultural competence in foreign language classes]. Theoretical and didactic philology. PereyaslavKhmelnytskiy.pp. 64-70. [in Ukrainian]. 
11. Krychevskyi, V. Yu. (1987). Professyohramma dyrektora shkoly. Problemy povyshenyia kvalyfykatsyy rukovodytelei shkol [Professional profile of the school principal. Problems of improving the qualifications of school principals]. Moscov, p.120. [in Russian].

12.Kontseptsiia pedahohichnoi kompetentnosti maibutnikh uchyteliv u systemi stupenevoi pidhotovky spetsialistiv pochatkovoi lanky osvity [The concept of pedagogical competence of future teachers in the system of step-by-step training of specialists of the initial level of education]. Available at: www.kgpa.km.ua (Accessed 6 Apr. 2019). [in Ukrainian].

13. Kudriavtsev, T.V. (1985). Uchebnoe posobye po kursu "Psykholohyia" [A manual for the course "Psychology"]. Psychology of vocational education and upbringing. Moscow, 108 p. [in Ukrainian].

14.Kuzmyna, N. V. (2001). Akmeolohycheskaia teoryia povyshenyia kachestva podhotovky spetsyalystov obrazovanyia [Akmeological theory of improving the quality of training of education specialists]. Moscow, p.144. [in Russian].

15. Maksymenko, S.D. Struktura ta osobystisni determinanty profesiinoi samorealizatsii subiekta [Structure and personal determinants of professional selfrealization of the subject]. Available at: www.kgpa.km.ua (Accessed 6 Apr. 2019 ). [in Ukrainian].

Стаття надійшла до редакції 16.04.2019

УДК 373.3/.5.091.21“199”:37.014.5

DOI:

Алла Загородня, кандидат педагогічних наук, доцент, провідний науковий співробітник відділу історії та філософії освіти Інституту педагогіки НАПН Украӥни

\section{СПЕЦІАЛІЗОВАНІ ШКОЛИ ЯК ПРОВІСНИКИ ПРОФІЛЬНОГО НАВЧАННЯ У 90-Х РОКАХ ХХ СТОЛІТТЯ}

У статті висвітлюються питання профільного навчання у 90-х роках ХХ століття. Наведено перелік нормативно-правових документів в яких висвітлено стратегічні завдання реформування системи освіти та сфери загальної середньої освіти. Розкрито сутність поняття “профільне навчання” згідно до визначення Національної доктрини розвитку освіти в Україні на 2012 - 2021 рр. Визначено мету та завдання профільного навчання. Окреслено принципи на яких трунтується профільне навчання. Охарактеризовано основні етапи становлення та розвитку профілізації загальної середньої освіти в Україні у 90-роках ХХ століття.

Ключові слова: диференціація; профільне навчання; профілізація; спеціалізовані школи; середня освіта; 90-ті роки ХХ століття.

Jim.15.

Alla Zahorodnya, Ph.D. (Pedagogy), Associate Professor, Leading Researcher of the History and Philosophy of Education Department Institute of Pedagogics of National Academy of Sciences of Ukraine

\section{SPECIALIZED SCHOOLS AS A HARBINGERS OF PROFILE EDUCATION IN THE 90'S OFTHE XX CENTURY}

The article covers the issues of profile education in the 90 's of the XX century. The essence of the concept "specialized education" according to the definition of the National doctrine of education development in Ukraine for 2012 - 2021 years is disclosed. The purpose and main tasks of profile education are defined. The principles on which the profile education is based (furctions, variations and alternatives, continuity, flexibility, diagnostic and predictive realization) are outlined. The main stages of the formation and development of profiling of general secondary education in Ukraine in the 90 years of the XX century are characterized. The regularities of the functioning of the internal and external forms of differentiation of training are defined. The difference between profile and in-depth study is found out. Conceptual foundations of the "Concept of differentiation of education in secondary schools" (1990), the Law of Ukraine "About education" (1991), "Programs of development of national education for 1991-1995", "Concepts of the secondary school of Ukraine" (1991), "Provisional Regulations of Secondary School of Ukraine" (1992), "State National Program Education" ("Ukraine XXI Century") (1993), "Regulations on General Education Institution" (1993), "Concepts of the State Standard of General Secondary Education" (1996), "Concepts of Establishment of the Network of Secondary Education Institutions" (1996), The Resolution "On Approval of the Basic Curriculum for General Education Institutions" (1998) are disclosed. The stages of the organization of institutions focused 